\title{
The Effect of Multipass Strategy on Students' Reading Comprehension at Senior High School Level
}

\author{
Ahmad Jailani \\ Language Center of UIN SUSKA Riau \\ email: Ahmadjay26@gmail.com
}

\begin{abstract}
Being able to read in English is very important. Success in reading is the most necessary because it is a basic tool of education. Based on the syllabus of Islamic Senior high School Hidayatul Mubtadiin (MAHM), it is hoped that students should comprehend monolog texts in narrative, spoof and hortatory exposition forms well. After doing preliminary observation at MAHM, some of the students of the second year still had low ability in their reading comprehension. The dominant factors influencing their low reading comprehension are the lack of vocabulary and teaching strategy of reading comprehension. From the two of dominant factors, the researcher is interested to investigate about teaching reading comprehension. Thus, the researcher conducted a research on the effect of Multipass strategy on Reading comprehension. This research investigates students' reading comprehension taught by using multipass strategy at MAHM Siak Sri Inderapura. The design of this study was Quasiexperimental research by post-test only. The subject of this research was the second year students of MAHM. The total population was 42 students, and the sample was 42 students. Data were collected by using a test. Then, the data were analyzed by using t-test formula. It was found that there was a significant effect of using multi pass strategy on students' reading comprehension at MAHM.
\end{abstract}

Keywords: Multipass strategy, reading comprehension

\section{Pengaruh Stratefi Multipass Terhadap Pemahaman Membaca Siswa di Sekolah Menengag Atas}

\begin{abstract}
Abstrak
Mampu membaca teks bahasa inggris sangatlah penting. Kesuksesan dalam membaca merupakan hal yang paling diperlukan karena ia adalah alat dasar dari pendidikan. Berdasarkan silabus Madrasah Aliyah Hidayatul Mubtadiin (MAHM), siswa diharapkan mampu memahami teks monolog yang berbentuk narative, spoof, dan hortatory exposition dengan baik. Setelah dilakukan observasi awal di sekolah tersebut, beberapa siswa masih memiliki pemahaman membaca yang rendah. Factor yang paling dominan yang mempengaruhi rendahnya kemampuan membaca mereka adalah kurangnya kosakata dan strategi pengajarannya. Dari dua factor tersebut, peneliti tertarik untuk mengisvestigasi strategy yang diterapkan dalam pengajaran pemahaman membaca. Jadi, peneliti melakukan penelitian tentang pengaruh strategi Multipass terhadap pemahaman
\end{abstract}


membaca. Penelitian ini menginvestigasi pemahaman membaca siswa yang diajar dengan menggunakan strategi Multipass di MAHM Siak Sri Inderapura. Desain penelitian dalam studi ini menggunakan Kuasi-eksperimen dengan melihat test akhir saja. Subjek penelitian ini adalah siswa kelas 2 MAHM. Total populasi 42 orang, dan seluruhnya dijadikan sample, yaitu 42 orang. Data diperoleh dengan mengunakan tes. Kemudian, data dianalisis menggunakan rumus T-test. Dari penelitian ini didapatkan kesimpulan bahwa ada pengaruh yang signifikan dari penggunaan strategy Multipass terhadap pemahaman mambaca siswa di MAHM.

Kata Kunci : srategi Multipass, pemahaman membaca

\section{INTRODUCTION}

Reading is one of the subjects to get information and knowledge about everything those readers need and to catch the messages or information from written text. According to Nunan in Anderson (2003), "Reading is a fluent process of readers combining information from a text and their own background knowledge to build meaning. Baker and Brown (2002) in Dorn and Soffos also states that reading is a complex process involving a network of cognitive actions that work together to construct meaning. Then, Johnson (2008) states that reading is the act linking one idea to another. While, Kustaryo (1998) underlines that the main thing that should be considered in reading process is reading comprehension which means understanding the text that has been read by the reader. Comprehension involves understanding vocabulary, seeing the relationship among words and concepts, organizing ideas, recognizing the author purposes, making judgment and evaluating. The related important skill in reading comprehension is grasping the main idea from reading paragraph or passage. Irwin (1986) says,

"Reading comprehension is a
process of using one's own
prior experience (reader
contact) and the writer cues
(text context) to infer the
author's intended meaning. This
process can involve
understanding and selectively
recalling ideas in individual
sentences (micro processes),
inferring relationships between
clauses and/or sentences
(integrative processes),
organizing ideas around
summarizing ideas (macro
processes), and making
inferences not necessarily
intended by the author
(elaborative processes)"

Reading ability is very important, and it is one of the four language skills that should be mastered by students at all grade levels. Being able to read in English is very important as it is known that success in reading necessary since it is a basic tool of education. Patel and Jain (2008) states that reading is the most reading is the most useful and important skill of the others, that are speaking, listening and writing. This is based on the fact that school 
subjects in primary schools need students' reading comprehension to understand. In high schools and colleges, reading ability becomes even more important. Through reading, readers acquire new ideas, obtain needed information, seek support for their ideas and broaden their interest. They can also get the message the writer had expressed.

Because of the importance of reading, it needs a serious attention in learning reading from both learners and teachers. It becomes a great challenging act for the teacher to teach reading, what kind of methods they use, and what kind of reading text that they give. There are some key principles of teaching reading according to Anderson (2003):

\section{a. Exploit the reader's background knowledge}

A reader's background knowledge has important role in reading comprehension. Background knowledge includes all of the experiences that a reader brings to a text: life experience, educational experiences, knowledge of how texts can be organized rhetorically, knowledge of how one's first language works, knowledge of how the second language works, and cultural background and knowledge. Reading comprehension can be significantly enhanced if background knowledge can be activated by setting goals, asking question, making prediction, teaching text structure, and so on. If students are reading on an unfamiliar topic, you may need to begin the reading process by building up background knowledge.
An interesting concept to consider related to the role of background knowledge is the negative influence it may have. Incorrect background knowledge can hinder comprehension. For example, some readers may have misconceptions about how AIDS is contracted. Some may believe that you can get it by touching someone suffering it or swimming in a pool with him. These misconceptions may interfere with a reading passage on it, and you may have to correct the background knowledge through: a. pre-reading activity before reading comprehension can be achieved.

\section{b. Build a strong vocabulary base.}

Recent research emphasized the important of vocabulary to successful reading. Basic vocabularies should be explicitly taught and L2 readers should be taught to use contest to effectively guess the meanings of less frequent vocabulary. Special terminology is easier for the reader of academic texts to cope than general vocabulary". They stress the great need for a teaching program that builds general, basic vocabulary. Vocabulary instruction enhanced by asking three questions from nation: a. What vocabulary do my learners need to know?; b. How will they learn this vocabulary?; c. Ho can I best test to see what they need to know and what they now know?

\section{c. Teach for comprehension}

In many reading instruction programs, more emphasis and time may be placed on testing reading comprehension then on teaching readers how to comprehend. 
Monitoring comprehension is essential to successful reading. Part of that monitoring process includes verifying that the prediction being made are correct and checking that the reader is making the necessary adjustments when meaning is not obtained. Cognition can be defined as thinking. Metacognitive can be defined as thinking about our thinking. In order to teach for comprehension, reader must monitor their comprehension processes and be able to discuss with the teacher and/or fellow readers what strategies they use to comprehend. By doing this, the readers use both their cognitive and metacognitive skills.

\section{d. Work in increasing reading rate}

One great difficulty in the second language reading classroom is that even when language learners can read, much of their reading is not fluent. Often, in our effort to assist students in increasing their reading rate, teacher overemphasizes accuracy which impedes fluency. The teacher must work towards finding a balance between assisting students to improve their reading rate and developing reading comprehension skills. It is very important to understand that the focus is not to develop speed reader as one who reads at a rate of 200 words-per-minute with at least 70 percent comprehension.

One focus here is to teach readers to reduce their dependence on a dictionary. Skills such as scanning, skimming, predicting, and identifying main ideas, get students to approach reading in different ways. Readers should spend more time analyzing and synthesizing the content of the reading, and not focusing on moving through the passage one word at a time. Part of the joy of reading is being able to pick up a book and comprehend it, without having to struggle through the task of reading.

\section{e. Teach reading strategies}

Strategies are the tools for active, self-directed involvement that is necessary for developing communicative ability. Strategies are not single event, but rather a creative sequence of events that learners actively use. This definition underscores the active role that readers take in strategic reading. To achieve the desire results, students need to learn how to use a range of reading strategies that match their purposes for reading. Teaching how to use the strategy should be a prime consideration in the reading classroom. Some of the researches that I have done indicate that "there is no single set of processing strategies that significantly contributes to success..." in second language reading tasks. Strategic reading means not only knowing what strategy to use, but also knowing how to use and integrate a range of strategies.

A good technique to sensitize students to the strategies they use is to get them to verbalize (or talk about) their thought processes as they read. Readers can listen to the verbal report of another reader who has just read the same material, and it is often revealing to hear what other readers have done to get meaning from a passage. I use this technique in my reading classes to get students to become more aware of their reading strategies and to be able to describe what those strategies are. 


\section{f. Encourage readers to transform strategies into skills}

Strategies can be defined as conscious actions that learners take to achieve desired goals or objectives, while a skill is a strategy that has become automatic. This characterization underscores the active role that readers play in strategic reading. As learners consciously learn and practice specific reading strategies, the strategies move from conscious to unconscious; from strategy to skill. For example, guessing the meaning of unknown vocabulary from context can be listed as both a strategy and a skill in reading texts. When a reader is first introduced to this concept and is practicing how to use context to guess the meaning of unfamiliar vocabulary he or she is using a strategy. The use of the strategy is conscious during the learning and practice stages. As the ability to guess unfamiliar vocabulary from context becomes automatic, the reader moves from using conscious strategy to using an unconscious skill. The use of the skill takes place outside the direct consciousness of the reader. The goal for explicit strategy instruction is to move readers from conscious control of reading strategies to unconscious use of reading skills.

\section{g. Build assessment and evaluation into your teaching}

Assessing growth and development in reading skills from both a formal and an informal perspective requires time and training. Both quantitative and qualitative assessment activities should be included in the reading classroom. Quantitative assessment will include information from reading comprehension tests as well as reading rate data. Qualitative information can include reading journal responses, reading interest surveys, and responses to reading strategy checklist.

\section{h. Strive for continuous improvement as a reading teacher}

The quality of the individual teacher is integral to success on second/foreign language readers. Reading teachers need to be passionate about their work. They should view themselves as facilitators, helping each reader discovers what works best. Integrating the key principles discussed above can lead to more effective reading instruction in the second language classroom. The good reading teacher actively teaches students what to do. To succeed, you need more than classroom tips and techniques: you need to understand the nature of the reading process.

Based on the preliminary research at MAHM, many students have difficulties in comprehending text. They feel difficult to find main idea, synonym, antonym, detail information, and even reference. Those conditions lead to the assumption that one of the factors influencing the students' failures is inappropriate strategy used in reading. One of the strategies which can deal for reading in Multipass strategy. Klinger, Vaughn, and Boardman (2007) states that Multipass strategy has purpose to help students to find and remember key information in the passage. Besides, Stout (1996) states that 
multipass strategy has been studied for its effectiveness. It is also suitable for students at ages 14-18 (Rollanda, 2011)

Multipass is a strategy developed by Schumaker et. al in 1984. Multipass is a suite of strategies intended to improve reading comprehension, learning acquisition, and generalization and paraphrasing skills steps approach for systematic rereading of expository text. It includes three steps approach for systematic rereading of expository text as Kumara and Srivastava (2005) states that Multipass strategy is a strategy that students make three passes (Survey Pass, Size- Up Pass, and Sort-out Pass) through an expository text. Then, Cummings (2000) states that Multipass strategy is a skill that needs to be taught and practice. It is useful for the students because some of the texts on their handbook are expository text, moreover most of scientific textbook are in expository forms.

The advantage of Multipass strategy is that registration of information in long-term memory is enhanced by going over the reading several times with different goals and mind. In addition, the approach may be used to improve understanding of reading in a variety of subject. Similarly, it may be used for reading textbook assignment as well as journal, articles, and other forms of texts. By producing written materials and providing review of readings, multipass aids in exam preparation. (Mike, 2011)

According to Harris and Graham in Vaughn \& Klinger (2007), the teaching process can be done as following steps: a. During the first pass, called "Survey," students spend about 3 minutes skimming the text to become familiar with its main ideas and organization. They paraphrase the title of the chapter, note how the chapter relates to other chapters and the unit of study, and scan the chapter's introduction, headings, and summary. b. During the next pass, called "Sort-out," they look for specific information in the text. They can do this by reading the questions at the end of the chapter and guessing at the answers, or they might turn each section heading into a question and skim the section to find the answer. Students also make study cards for key terms highlighted in the text. c. During the last pass, called "Size-up," they read the text to find the correct answers to the questions from the previous step. They also test themselves with the study cards they made earlier.

While, Schumm (2006) on her book simpler than above. She stated that in Multipass strategy, the students make three steps approach for systematic rereading of expository text. First, students read an assignment to get an overview of the topic and to detect the organization of the text. Second, students read comprehension questions, guess an answer based on their reading of the text and then confirm their guess with a rereading of the passage. Third, students prepare for tests by quizzing themselves on comprehension questions. Teachers teach students how to use the Multipass strategy by explaining and modeling each of these three steps. Students then take turns verbally rehearsing each step until they can perform it correctly 
without prompts. They then practice the strategy with a text at their reading level, with feedback from the instructor. As students become more proficient using Multipass, they should try it with more difficult texts. The teacher evaluates students on each step of Multipass and checks their understanding of the text with a comprehension test at the end of each completed chapter.

\section{METHOD}

In this study, the writer used Quasi-Experimental design with posttest-only design. To apply this research, the writer took two classes, science class as experimental class and social class as control class (chosen by lottery). The writer gave treatment for experimental class only. Then, the writer gave them a posttest to find out the effect of the strategy applied by the researcher. During the treatment, the writer cooperated with the observer to monitor in teaching learning process. Finally, the writer would like to show the reader the design of the research by Cresswell (2008) as follows:

Table 1. Research Design

\begin{tabular}{lcc}
\hline \multicolumn{1}{c}{ Group } & Treatment & $\begin{array}{c}\text { Post- } \\
\text { test }\end{array}$ \\
\hline Experimental & $\mathrm{X}$ & $\mathrm{X}$ \\
Control & $\mathrm{O}$ & $\mathrm{X}$ \\
\hline
\end{tabular}

The subject of the research was the second year students of MAHM Bandar Sungai Siak Sri Indrapura Regency, and the object of the research was the effect of using Multipass strategy on reading comprehension in hortatory exposition text of the second year students at MAHM. The population of the research was the second year students of MAHM Bandar Sungai Siak Sri Indrapura Regency in 20112012 academic years. The total number of the population was 42 students, which consisted of two classes, science by 21 students and social class by 21 students. Cluster random sampling was used to determine the samples. Then by using lottery, it was decided that science class was as an experimental class and another one was a control class. Furthermore, it was assumed that the two classes had the same ability by considering some conditions below:

1. Both of them use the same curriculum

2. Both of them use the same book

3. Both are taught by the same teacher

To collect data of the students' reading comprehension after being taught by using Multipass strategy, the writer used a test. Because the method chosen by writer is quasi-experimental by post-test design, the test was given once after six times of treatment. In giving the assessment, the writer correlated it to the goal or purpose of the reading in curriculum. The test used by the writer was multiple choice test. The multiple choices test was a test designed by using four options or choices and the students chose the appropriate one, which was based on the question. This technique could assess the students' reading comprehension. Before the test was given to the students, it was tried out in order to find its validity and reliability. The data of students' posttest of experimental and control groups were analyzed by using 
statistical analysis. The different mean is analyzed by using T-test formula.

\section{RESULT AND DISCUSSION}

The researcher taught directly for six meetings in the experimental class. The procedures of implementing Multipass strategy are: first, the teacher asks students to read an assignment to get an overview of the topic. At this stage, students should read fast the text to get an overview or general idea; second, the teacher asks students to detect the organization of the text. At this stage. Students should understand the organization of the text. Since the text used is a hortatory exposition, students will try to find the thesis, arguments, and recommendation; third, the teacher asks the students to read comprehension questions. This stage asks students to read the questions provided below the text; fourth, the teacher asks the students to guess an answer based on their reading of the text. Here the students will try to make answer of the questions from their previous reading; fifth, the teacher asks students to confirm their guess with a rereading of the passage. After answering the questions, the students should reread the text to make sure their answer correct; sixth, the teacher asks students to prepare for tests by quizzing themselves on comprehension questions. This stage require students to make their own questions related to the text and try to answer them. The important thing that should not be neglected by the teacher before the practice is that he should model how to do the procedures.

After being taught for six meetings, the experimental group was given a test to get the data of their reading comprehension. The distribution of frequency of students reading comprehension of hortatory exposition of experimental class can be seen in the following table:

Table 2. The Frequency Distribution of Students' Post-test Scores of Experiment class

\begin{tabular}{ccccc}
\hline Score & Frequency & Percent & Valid Percent & Cumulative \\
\hline 40 & 1 & 4.76 & 4.76 & 4.76 \\
45 & 1 & 4.76 & 4.76 & 9.52 \\
50 & 2 & 9.52 & 9.52 & 19.04 \\
55 & 3 & 14.28 & 14.28 & 33.32 \\
60 & 1 & 4.76 & 4.76 & 38.08 \\
65 & 2 & 9.52 & 9.52 & 47.6 \\
70 & 4 & 19.05 & 19.05 & 66.65 \\
75 & 2 & 9.52 & 9.52 & 76.17 \\
80 & 3 & 14.28 & 14.28 & 90.45 \\
85 & 2 & 9.52 & 9.52 & 100.0 \\
Total & 21 & 100.0 & 100.0 & \\
\hline
\end{tabular}


Referring on the table above, it shows that there was 1 student who got 40 (4.76\%), 1 student got 45 (4.76\%), 2 students got 50 (9.52\%), 3 students got 55 (14.28\%), 1 student got 60 (4.76\%), 2 students got 65 (9.52\%), 4 students got $70(19.05 \%)$, 2 students got $75(9.52 \%), 3$ students got 80 (14.28\%), 2 students got 85 (9.25). So, it can be seen that the total number of the students was 21 students. The highest score was 85 and the lowest score was 40. The highest frequency was 4 at the score of 70 .

While, The distribution of frequency of students reading comprehension of hortatory exposition of experimental class can be seen in the following table:

Table 3. The Frequency Distribution of Students' Post-test Scores of Control class

\begin{tabular}{ccccc}
\hline Score & Frequency & Percent & Valid Percent & Cumulative \\
\hline 30 & 1 & 4.76 & 4.76 & 4.76 \\
35 & 2 & 9.52 & 9.52 & 14.28 \\
40 & 2 & 9.52 & 9.52 & 23.8 \\
45 & 1 & 4.76 & 4.76 & 28.56 \\
50 & 1 & 4.76 & 4.76 & 33.32 \\
55 & 3 & 14.28 & 14.28 & 47.6 \\
60 & 6 & 28.6 & 28.6 & 76.2 \\
65 & 3 & 14.28 & 14.28 & 90.48 \\
70 & 1 & 4.76 & 4.76 & 95.24 \\
75 & 0 & 0 & 0 & 95.24 \\
80 & 1 & 4.76 & 4.76 & 100.0 \\
Total & 21 & 100.0 & 100.0 & \\
\hline
\end{tabular}

Referring on the above table, it shows that there was 1 student who got $30(4.76 \%), 2$ students got 35 (9.52\%), 2 students got 40 (9.52\%), 1 student got 45 (4.76\%), 1 students got 50 (4.76\%), 3 students got 55 (14.28\%), 6 students got $60(28.6 \%), 3$ students got $65(14.28 \%), 1$ student got 70 (4.76\%), 0 student got 75 $(0 \%)$, and 1 student got $80(4.76 \%)$. So, it can be seen that the total number of the students was 21 students. The highest score was 80 and the lowest score was 30. The highest frequency was 6 at the score of 60 .

The analysis of data of the students reading comprehension for the experimental group is explained in the following table: 
Table 4. The Classification of Post Test Experimental Group

\begin{tabular}{clccc}
\hline No & Category & Score & Frequency & Percentage \\
\hline 1 & Very good & $80-100$ & 5 & $23.8 \%$ \\
2 & Good & $70-79$ & 6 & $28.6 \%$ \\
3 & Enough & $60-69$ & 3 & $14.28 \%$ \\
4 & Less & $50-59$ & 5 & $23.8 \%$ \\
5 & Bad & $0-49$ & 2 & $9.52 \%$ \\
\hline
\end{tabular}

Based on the table above, classification of the experimental group at the second year students of Islamic Senior High School Hidayatul Mubtadiin Bandar Sungai, the output from 21 students shows that the frequency of category number 1 is 5 $(23.8 \%)$, number 2 is $6(28.6 \%)$, number 3 is $3(14.28 \%)$, number 4 is $5(23.8 \%)$, and number 5 is 2 (9.52\%). The table above shows that the highest percentage of classification of experimental group is
$28.6 \%$ with category good. Then, the result of analysis on the students reading comprehension, the mean score was 65.71. It means the students' reading comprehension of hortatory exposition text includes in enough category.

While, the analysis of data of the students reading comprehension for the experimental group is explained in the following table:

\section{Table 5. The Classification of Post Test Control Group}

\begin{tabular}{clccc}
\hline No & Category & Score & Frequency & Percentage \\
\hline 1 & Very good & $80-100$ & 1 & $4.76 \%$ \\
2 & Good & $70-79$ & 1 & $4.75 \%$ \\
3 & Enough & $60-69$ & 9 & $42.8 \%$ \\
4 & Less & $50-59$ & 4 & $19.04 \%$ \\
5 & Bad & $0-49$ & 6 & $28.6 \%$
\end{tabular}

Based on the table above, classification of control group at the second year students of Islamic Senior High School Hidayatul Mubtadiin Bandar Sungai the output from 21 students show that the frequency of category 1 is $1(4.76 \%)$, number 2 is $1(4.76 \%)$, number 3 is 9 $(42.8 \%)$, number 4 is $4(19.04 \%)$, number 5 is $6(28.6 \%)$. The table above shows that the highest percentage of classification of control group is $42.8 \%$ with category enough. Then, the result of analysis on students reading comprehension, the mean score was 54.52. It means that students reading comprehension of hortatory exposition text includes in Less category.

While the result of the standard deviation of post-test for each class is as follows:

a. Standard deviation for range score of experimental class

$$
\begin{aligned}
\operatorname{SD} x=\sqrt{\frac{\sum x^{2}}{N}} & =\sqrt{\frac{3180.13}{21}} \\
& =\sqrt{151.43}=12.3
\end{aligned}
$$


b. Standard deviation for range score of control class

$$
\begin{aligned}
\operatorname{SD} x=\sqrt{\frac{\sum x^{2}}{N}} & =\sqrt{\frac{3295.23}{21}} \\
& =\sqrt{156.91}=12.53
\end{aligned}
$$

From the calculation above, it can be stated that:

$$
\begin{aligned}
& \mathrm{SD} x=12.3 \\
& \mathrm{SD} y=12.53 \\
& \mathrm{M} x=65.71 \\
& \mathrm{M} y=54.52
\end{aligned}
$$

$$
\begin{gathered}
\mathrm{t} o=\frac{M x-M y}{\sqrt{\left(\frac{S D_{X}}{\sqrt{N-1}}\right)^{2}+\left(\frac{S D_{y}}{\sqrt{N-1}}\right)^{2}}} \\
=\frac{65.71-54.52}{\sqrt{\left(\frac{12.3}{\sqrt{20}}\right)^{2}+\left(\frac{12.53}{\sqrt{20}}\right)^{2}}} \\
=\frac{11.19}{\sqrt{\left(\frac{12.3}{\sqrt{4.47}}\right)^{2}+\left(\frac{12.53}{\sqrt{4.47}}\right)^{2}}} \\
=\frac{11.19}{\sqrt{(2.75)^{2}+(2.8)^{2}}} \\
=\frac{11.19}{\sqrt{7.56+7.84}} \\
=\frac{11.19}{\sqrt{15.4}} \\
=\frac{11.19}{3.92} \\
=2.85
\end{gathered}
$$

Based on the calculation above, it is clear that to is 2.85 . To know whether there is significant effect or not between the use of Multipass strategy toward reading comprehension, we need to obtain the degree of freedom by using the following way:
$\mathrm{Df}=(\mathrm{N} 1+\mathrm{N} 2)-2$

$=(21+21)-2$

$=42-2$

$=40$

The above calculation results that the degree of freedom is 40 . The T-table at 5\% level of significance 2.02 , and $1 \%$ level of significance is 2.72. So the writer could conclude that it is higher than table of both in $5 \%$ and $1 \%$ level of significance. It can be concluded $2.02<2.85>2.72$. Therefore, the first hypothesis can be accepted and it means that there is significant effect of using Multipass toward reading comprehension at the second year students of Islamic Senior High School Hidayatul Mubtadiin Bandar Sungai.

As Stout states on his book that multipass strategy has been studied for its effectiveness, it was proved that multipass strategy gave positive effect on students reading comprehension of hortatory exposition text. It can be seen form the difference of the mean score between experimental group with mean score 65.71 and control group with mean score 54.52 . It also can be seen from the result of T-test above where $2.02<2.85>2.72$.

\section{CONCLUSION SUGGESTION}

AND

The students' reading comprehension of hortatory exposition text taught by Multipass Strategy was categorized into enough level. The students' reading comprehension of hortatory exposition text taught without using multipass strategy was categorized into less level. There is significant 
effect between students' reading comprehension of hortatory exposition text who are taught by using Multipass strategy and those who are taught without using Multipass strategy at the second year students of MAHM. Students who were taught by usingMultipass strategy seemed to get faster in finishing the test than those who were not.

Considering the effect
Multipass Strategy on reading comprehension of hortatory exposition text, the researcher would like to give some suggestions as follows:

For teachers

1. It is recommended to teacher to implement Multipass strategy in teaching reading, especially for hortatory exposition text.

2. The teacher builds a favorable atmosphere in teaching-learning process, because the conductive condition in teaching would become one asset to carry the success of material to be taught. It also can make Multipass strategy work better.

For students

1. The students should try to understand to implement Multipass strategy in reading text and practice in the classroom.

2. The students pay more attention to when the teacher explains and how to use Multipass strategy

3. The students should try and practice the Multipass strategy by themselves in their class or other places. Finally, the researcher considers that this study still needs validation from the next researcher that has the same topic as this study.

For future researchers

1. The future researchers may conduct an action research to find how Multipass strategy can improve students reading comprehension well.

2. The future researchers may conduct a research with a longer time and a wider scope by including intervening/ moderating variables.

\section{REFERENCES}

Anderson, Neil, Reading, in Practical English Language Teaching. First Edition, Editor: David Nunan, Singapore: McGrawHill Company, Inc., 2003.

Creswell, John, Educational Research. New Jersey: University of Nebraska, 2008.

Cummings, Carol, Winning Strategies for Classroom Management. Alexandria: Library of Congress Cataloging data, 1999.

Dorn, J. Linda, Soffos, and Carla, Teaching for Deep Comprehension: A Reading Workshop Approach. Portland, Maine: Stenhouse Publishers, 2005.

Irwin, Judith Westphal, Teaching Reading Comprehension Process. New Jersey: PrenticeHall, 1986.

Janette, K.Klingner, Vaughn, Sharon, and Boardman, Alison, Teaching

Reading Comprehensionto Students with Learning 
Difficulties. New York: The Guilford Press, 2007

Johnson, P. Andrew, Teaching Reading and Writing: A Guide Book for Tutoringand Remediating Students. New York: Rowman and Littlefield Education, 2008.

Kumara, S., Srivastava, D.S., Education: Skills and Competencies. Delhi: Mehra Offset Press, 2005.

Kustaryo, S, Reading Techniques for College Students. Jakarta: Departemen Pendidikan dan Kebudayaan, 1998.

Mike, Multipass Strategy for Reading. Posted on Monday, September 26, 2011 at http://www.saddlebackdsps.co $\underline{\mathrm{m}}$

O'Connor, E. Rollanda and Vadasy, F. Patricia, Handbook of ReadingInterventions. New York: The Guilford Press, 2011.
Patel, M. F, Jain, M. Praveen, English Language Teaching (Methods, Tools, andTechniques). First Published. Jaipur: Sunrise Publishers and Distributors, 2008.

Schumaker, et al, Multipass: A Learning Strategy for Improving ReadingComprehension. .

Retrieved on January, 18, 2012 at A research at http://www.eric.ed.gov/ ERICWebPortal/ search/simpleSearch, 1981.

Schumm, Jeanne Shay, Reading Assessment and Intruction for All Learners. New York: The Guilford Press, 2006.

Stout E.Chris, The Integration of Psychological Principles in Policy Development. New york: An Imprint of Greenwood PublishingGroup, Inc., 1996. 